\title{
The Evaluation of Paket $C$ Program in Improving the Learning Quality of Learning Citizens at Sanggar Kegiatan Belajar Cerme Gresik
}

\author{
I Ketut Atmadja Johny Artha \\ Non-Formal of Education Department \\ Universitas Negeri Surabaya, Indonesia \\ ketutatmadja@unesa.ac.id
}

\section{Widodo}

Non-Formal of Education Departement

Universitas Negeri Surabaya, Indonesia widodo48@ymail.com

\author{
Indrawati Theresia \\ Non-Formal of Education Department \\ Universitas Negeri Surabaya, Indonesia \\ ininon@hotmail.com \\ Mustakim \\ Department of Early Childhood Islamic Education \\ Universitas Muhammadiyah Gresik, Indonesia \\ mustakim@umg.ac.id
}

\begin{abstract}
Digital era education becomes a challenge for citizens learning Paket $C$. Along with the progress of the times the improvement in the quality of education is directly proportional to the competencies of learning citizens. The Paket $C$ program is a program in the non-formal education pathway that is organized in stages and structured. Learning citizens as adults to receive education have not been maximally facilitated in the formal education pathway equivalent to high school (high school) or Madrasah Aliyah (MA). This research was conducted on learning citizens of Paket $C$ at Sanggar Kegiatan Belajar (SKB) Cerme Gresik. The purpose of this study was to find out how the description of the Paket $C$ program at SKB Cerme Gresik, as well as to describe the quality of learning the learners of Paket $C$ at the SKB Gresik. In this study using Mixed Methods method with qualitative and quantitative approaches. The results of this study illustrate that the evaluation of the Paket $C$ program is carried out in five stages such as planning, organizing, mobilizing, coaching, and evaluating. And the quality of learning can be seen from the tutors who have scientific qualifications that are appropriate to the subject. And the results of pre-test and post-test learning showed an increase in the quality of learning before and after learning.
\end{abstract}

Keywords: non-formal education, paket c, learning quality, learning citizens, and program evaluation

To realize quality education it is necessary to

\section{INTRODUCTION}

Education in the digital era is the carrying capacity of the community in entering the business and industrial world. Through education, learning citizens can access higher education. The carrying capacity of improving the quality of learning becomes an important value in increasing the competence of graduates from Paket $\mathrm{C}$ (High School Equivalency). Educational services in Indonesia recognize education as divided into three education centers. Tri education centers include formal education, non-formal education, and informal education.

Formal education is a structured and tiered education pathway consisting of basic education, secondary education, and higher education. Non-formal education is a channel of education outside of formal education that can be implemented in a structured and tiered manner, and informal education is a path of family and environmental education [1].

In actual implementation, formal education has not been maximized in facilitating the community. This is seen in adults as citizens learning to pursue Package C. Therefore, non-formal education is an alternative in facilitating adults to learn. The general Paket $\mathrm{C}$ program (High School Equivalency) is equivalent to High Schools (SMA) providing non-formal education services for anyone who needs secondary education and cannot be fulfilled through formal education channels [2]. conduct a program evaluation. Evaluation is an activity to gather information about the workings of something, which then information is used to determine appropriate alternatives in making a decision [3]. Information collected as material for improving the quality of learning of learning citizens.

While the evaluation of the program is a framework of activities carried out deliberately and carefully to find out the level of implementation or success of a program by knowing the effectiveness of each component, both for the current program and programs that have passed [4].

Citizens who are active in learning, have a religious spiritual, can control themselves, have personality, intelligence, and noble character will be realized if the learning citizens have fulfilled the 12 year compulsory education. The gross enrollment rate (GER) of high school / MA / Package C graduates will be seen if more students receive 12-year compulsory education. The government through the education development program is described in Mission $5 \mathrm{~K}$. They are: (1) availability of educational services, (2) affordability of education services, (3) improving the quality of education, (4) realizing equality for education, and (5) ensuring certainty get education services [5].

Sanggar Kegiatan Belajar Cerme Gresik is a nonformal educational institution that organizes the equivalence program paket C. Based on Dwinata's 
research at Gresik SKB, the current SKB programs currently being implemented by the tutors are still not suitable or have not achieved maximum results compared with targets or targets specified in the SKB operational manual. Factors affecting the discrepancy between the implementation of the program or the tasks carried out by the Civil Service Learning Unit and the planning contained in the operational guidelines of the SKB. Several factors include internal and external factors [2].

Internal factors are factors that originate from within the tutor learning such as motivation in work, education, and experience, potential, and mastery of skills. External factors are factors from outside the individual such as; SKB head leadership, work environment, facilities or infrastructure, and conditions in the community itself. Through facilities and infrastructure, it is expected that the program can run optimally in accordance with what has been planned [6].

The obstacle experienced by tutors in teaching and learning activities is the mismatch between the implementation of the program or the tasks carried out by the Civil Service Learning Unit and the planning contained in the operational guidelines of the SKB. Tutors who handle two subjects at the same time outside their educational qualifications, active learning citizens who are lacking, tutors lack understanding of material outside of their educational qualifications, tutors rarely use learning implementation plans (RPP) when teaching, many materials are still not delivered to learning citizens [2].

According to BPS data, the school expectations (APS) of citizens learning in Gresik Regency during the last five years from 2013 to 2017 experienced a relatively small increase. This is as in table 1.1 as follows:

Table 1.1: School Expectation Rates in Gresik Regency

\begin{tabular}{|l|c|c|c|c|c|}
\hline \multirow{2}{*}{ The region } & \multicolumn{5}{|c|}{ School Expectation Rate } \\
\cline { 2 - 6 } & 2017 & 2016 & 2015 & 2014 & 2013 \\
\hline $\begin{array}{l}\text { Gresik } \\
\text { Regency }\end{array}$ & 13.70 & 13.69 & 13.19 & 13.17 & 12.85 \\
\hline
\end{tabular}

Source: BPS in 2019

School expectations for 2013-2014 increased by $0.32 \%$, in $2014-2015$ it increased by $0.02 \%$, for 2015 2016 it increased by $0.5 \%$, while for 2016-2017 it increased by $0.01 \%$. From the school expectation rate for 5 years in Gresik Regency, there was no significant increase [7].

While the gross enrollment rate (APK) of education in Gresik Regency according to BPS data from 2015-2019 for the level of education from elementary school to secondary school also did not experience a significant increase. The condition of gross participation rates in Gresik Regency can be seen in Table 1.2 as follows:

Table 1.2: Rough Participation Rates Rates in Gresik Regency

\begin{tabular}{|l|l|l|l|}
\hline \multirow{2}{*}{ Educational Level } & \multicolumn{3}{|c|}{ The Gross Enrollment Rate } \\
\cline { 2 - 4 } & 2017 & 2016 & 2015 \\
\hline Elementary school & 106.79 & 108.17 & 108.67 \\
\hline Middle school & 92.22 & 92.54 & 91.42 \\
\hline High school & 81.43 & 81.23 & 116.20 \\
\hline
\end{tabular}

Source: BPS in 2019

In table 1.2 , the gross participation rate of Gresik Regency illustrates that from 2015-2017 the gross enrollment rate starting from elementary schools/Madrasah Ibtidaiyah decreased from 108.67 to
108.17, and in 2017 it dropped to 106.79. Whereas in 2015 junior high schools/Madrasah Tsanawiyah starting from 91.42 to 92.54 , and in 2017 decreased to 92.22 . For senior high school/ Madrasah Aliyah, from 2015-2016, the gross enrollment rate decreased significantly from 116.20 to 81.23 , and in 2017 , it increased to 81.43 [8].

The condition of gross participation rates that are not stable in Gresik Regency is an obstacle for formal education. So it is necessary to take part in non-formal education in overcoming the problem of the lack of gross participation rates and expectations of community schools in Gresik Regency.

Based on the preliminary study and the results of a literature study conducted by researchers, efforts to improve the quality of learning of learning citizens by evaluating the program. The evaluation of the equality program is expected to provide input in improving the quality of learning of learning citizens at the Sanggar Kegiatan Belajar Cerme Gresik.

\section{METHOD}

This research uses mixed methods. It combines quantitative and qualitative methods. Mixed methods research design is a procedure for collecting, analyzing, and "mixing" quantitative and qualitative methods in a study or series of studies to understand research problems [9].

The research approach used is a quantitative and qualitative approach, in Indonesian a mixed method. Quantitative data, such as scores on various instruments, obtain certain numbers that can be analyzed statistically, can produce results to access the frequency and strength of trends, and can provide useful information, and qualitative data, such as open interviews that provide the actual words of people in research, offer many different perspectives on the research topic and provide a complex picture of the situation [9].

Whereas the design of this study uses Explanatory sequential design namely "... mixed methods may collect quantitative and qualitative information sequentially in two phases, with one data collection following and providing information on other forms of data collection." [9].

Visually the following in the Figure: 2.1 the following:

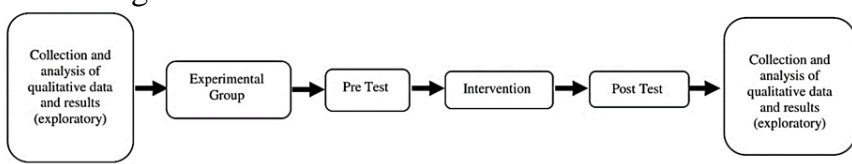

Figure 2.1: The Experimental Mixed-Methods Design [9]

Sequential explanatory model combination research methods are characterized by data collection and quantitative data analysis in the first stage, and followed by the collection and analysis of qualitative data in the second stage, in order to strengthen the results of quantitative research conducted in the first stage [10]. In this study using the Wilcoxon Test Signed Rank Test using SPSS statistics 22 for Windows and Microsoft Office Excel 2013.

The place of this research was conducted at Sanggar Kegiatan Belajar (SKB) Cerme Gresik, Jl. Jurit, Cerme Kidul, Cerme, Gresik Regency, East Java 61171. The reason for determining the place as a research location is because of the SKB Gresik is an institution that organizes Paket $\mathrm{C}$ program (High School 
Equivalency). And the subject of the study is four tutors and twenty learning citizens.

Data collection techniques in this study were by interview, observation, documentation and questionnaire. As for data analysis techniques with qualitative and quantitative analysis.

\section{RESULTS AND DISCUSSION}

\section{A. RESULTS}

The Overview of Paket $C$ Program at di Sanggar Kegiatan Belajar (SKB) Cerme Gresik

The evaluation of the equality program is examined from the description of the paket $C$ program. In the description of the paket $C$ program carried out by the Sanggar Kegiatan Belajar (SKB) Cerme Gresik, there are five stages including planning, organizing, mobilizing, coaching, and evaluating.

At the planning stage, the paket $C$ program aims to provide opportunities and opportunities for people who cannot experience formal education. The need for learning citizens to pursue the paket $C$ is to get a diploma and be used as a precondition for work. Whereas skills that are sought after by learning citizens include sewing for women, and gardening for men. Learning citizens of the paket $C$ is 18 years old for regular programs, and for nonregular programs, the average is over 25 years.

The advantage of the paket $C$ program is having flexible time so that learning citizens can adjust to nonregular working time. As for the regular for the learning time in accordance with the active day of school Monday through Friday. Barriers to learning citizens to take part in learning activities are the relative distance between work locations and places of study.

The paket $C$ program, in the recruitment of tutors, has a minimum undergraduate education qualification in all fields of study required by the SKB. And the age of tutors between 25-45 years and has the motivation to teach and educate learning citizens.

At the stage of organizing the equality program for Paket $C$, the program manager is the tutors of the Sanggar Kegiatan Belajar (SKB) Cerme, Gresik regency. With the aim of learning to provide knowledge, skills, and attitude planting in learning citizens. In the paket $C$ program, there are twenty 20 people of learning citizens. As well as the location of learning conducted at the SKB Cerme, Gresik Regency for the regular learning citizens at 07.00-14.00 WIB from Monday to Friday. As for Saturday for the development of talent interest activities.

Non-regular learning citizens, learning takes place on Saturdays and Sundays. With flexible time and adapted to the needs of learning citizens. In implementing learning using the K13 curriculum that is tailored to the needs of learning citizens. As well as learning methods using lectures, and brainstorming. Whereas tutor learning techniques is to use discussion and demonstration for learning skills.

The facilities and pre-learning of the paket $C$ program in their implementation use learning facilities in the SKB with 6 local classrooms that are already equipped with tables, chairs and white boards. Besides the library facilities in the SKB that are used as referrals for learning citizens in the learning process of the paket $C$. The process of the paket $C$ in the SKB, the learning citizens are free of charge, because the residents learn to get education fees from the government.
The mobilization phase of citizens to take part in learning activities in paket $\mathrm{C}$ has intrinsic and extrinsic motivation. At the intrinsic stage, learning citizens have high motivation to learn, seen from the enthusiasm for learning and the presence for learning every day. As for extrinsic factors, learning citizens get help with study costs and encouragement from parents to receive higher education.

At the stage of development of the paket C program in the SKB Cerme Gresik, it was carried out in three stages. They are supervision, investigation, and monitoring. The learning supervision stage is carried out by the tutor as the manager of the paket $\mathrm{C}$ program. The investigation phase is carried out by the subject tutor, and the learning monitoring stage is carried out by the tutor and tutor during the learning process.

At the learning assessment stage carried out through three stages including: initial assessment of activities, assessment of the learning process, and final evaluation of learning. The implementation of paket $\mathrm{C}$ for the initial assessment of activities is to look at the participation of learning citizens in the learning, and the accuracy of the arrival of learning citizens. The assessment of the learning process is carried out by the subject tutor. Tutors assess by looking at the activeness of learning citizens, neatness, attitudes, and creativity of citizens learning during studying. And the final assessment of learning is by holding a final examination both in theory and practice.

Improving the Quality of Learning for Learning Citizens of Paket C at Sanggar Kegiatan Belajar Gresik

The quality of learning is an indicator used in the assessment of learning on the Paket $\mathrm{C}$ program in the SKB Gresik. On the quality of learning of citizens learning package $\mathrm{C}$ to measure the level of achievement using pre-test and post-test assessments.

Table 3.1: Pre Test and Post test Quality of Learning in Citizens Learning of Package $C$ at SKB Cerme Gresik.

\begin{tabular}{|c|c|c|}
\hline \multirow{2}{*}{ No. Respondent } & \multicolumn{2}{|c|}{ Quality of Learning } \\
\hline & Pre test & Post Test \\
\hline 1 & 3,27 & 3,64 \\
\hline 2 & 3,09 & 3,55 \\
\hline 3 & 3,64 & 3,82 \\
\hline 4 & 3,36 & 3,45 \\
\hline 5 & 3,00 & 3,64 \\
\hline 6 & 3,00 & 3,36 \\
\hline 7 & 3,45 & 3,64 \\
\hline 8 & 2,91 & 3,27 \\
\hline 9 & 2,91 & 3,64 \\
\hline 10 & 3,73 & 3,82 \\
\hline 11 & 3,00 & 3,73 \\
\hline 12 & 2,91 & 3,73 \\
\hline 13 & 3,45 & 3,55 \\
\hline 14 & 3,09 & 3,82 \\
\hline 15 & 3,45 & 3,64 \\
\hline 16 & 2,91 & 3,91 \\
\hline 17 & 3,36 & 3,73 \\
\hline 18 & 3,55 & 3,64 \\
\hline 19 & 3,55 & 3,73 \\
\hline 20 & 3,55 & 3,64 \\
\hline
\end{tabular}

In table 3.1 the results of the pre-test and post-test learning quality of citizens learning, paket $\mathrm{C}$, in SKB Cerme Gresik. The following are the results of the Wilcoxon Signed Ranks Test, and are processed using SPSS statistics 22 for Windows and Microsoft Office Excel 2013 in table 3.2 as follows: 
Table 3.2 Ranks

\begin{tabular}{|ll|r|r|r|}
\hline \multicolumn{2}{|c|}{ Ranks } & & Mean & Sum of \\
& & $\mathrm{N}$ & Rank & \multicolumn{1}{c|}{ Ranks } \\
\hline Post Test - Pre Test & Negative Ranks & $0^{2}$ &, 00 &, 00 \\
& Positive Ranks & $20^{\mathrm{b}}$ & 10,50 & 210,00 \\
& Ties & $0^{\circ}$ & & \\
& Total & 20 & & \\
\hline
\end{tabular}

a. Post Test $<$ Pre Test

b. Post Test $>$ Pre Test

c. Post Test $=$ Pre Test

Output Table 3.2 Ranks can be interpreted as follows:

a. Negative ranks or the difference in negative values between the quality of learning of citizens learning from paket $C$ for pre-test and post-test is 0 , both for the value of N, Mean Rank, and Sum Rank. A value of 0 indicates no decrease from the pre test value to the post-test value.

b. Positive ranks or positive value difference in learning quality of citizens learning of paket $C$ for pre-test and post-test. In table 3.2 , the value of $\mathrm{N}$ is 22 positive data, which means that the 20 learning residents have improved the quality of learning from pre-test to posttest. Mean or the average has increased by 10.50 , while the number of positive rankings or sum of ranks is equal to 210.00 .

c. Ties are the similarity of pre-test and post-test values, in table 3.2 the ties value is 0 , so it can be said that there is no similar value between pre-test and post-test.

The basis for decision making in the Wilcoxon test is as follows:

a. If the value of Asymp.Sig. (2-tailed) is smaller than $<0.05$, then Ha is accepted.

b. Conversely, if the Asymp.Sig (2-tailed) value is greater than $>0.05$, then Ha is Rejected.

On the basis of decision making in the Wilcoxon test, the decision making and conclusion making are synchronized with Test Statistics in table 3.3 as follows:

Table 3.3

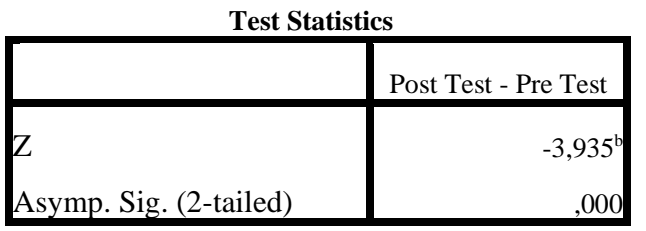

a. Wilcoxon Signed Ranks Test

b. Based on negative ranks

Based on the output in table 3.3 test statistics, it is known that Asymp.Sig (2-tailed) is worth 0,000. Because the value is 0,000 , it is smaller than $<0.05$, and it can be concluded that "Ha is accepted". This means that there are differences between learning outcomes before using a learning quality approach.

\section{B. DISCUSSION}

Overview of Paket C Program at Sanggar Kegiatan Belajar Cerme Gresik
The description of the Paket $\mathrm{C}$ program in its implementation has five interrelated stages. In the first stage, the planning phase of the paket $\mathrm{C}$ program. At this stage, learning citizens of paket $\mathrm{C}$ divided into two groups. Regular and non-regular groups. Tutors as program organizers at the planning stage identify needs for learning citizens. The results of identification that learners of non-regular want to learn to get a diploma as a requirement to enter the workforce.

Furthermore, the learners of regular want to study due to several obstacles, such as due to lack of family finances, and dropouts from formal schooling. Therefore, Paket $\mathrm{C}$ program as a solution in obtaining education equivalent to high school. Besides, in the Package C program, the learning community also gained skills. Skills taught include sewing and gardening. I have sewing skills for learners female and gardening skills for learners female. In addition to these skills, learning citizens are also given the freedom to choose the sports fields of interest.

Paket C program which is equivalent to high school has advantages over formal education, including: (1) learning time is more flexible, because there is a learning contract between learning citizens and tutors, (2) clothes for learning do not have to be the same, the important thing is polite and neat, (3) the curriculum taught is tailored to the needs of the learning citizens, (4) learning prioritizes practice rather than theory in class, (5) learning is not limited to the classroom, outside the classroom as well as a place for learning. "... Paket $\mathrm{C}$ was developed based on the following principles; centered on life, diverse and integrated, responsive to the development of science, technology and art, thorough and continuous, and the principle of lifelong learning" [11].

In the implementation of learning planning that is often constrained is the distance of learning citizens from the place of learning. Therefore, learning citizens need a relatively long time.

The paket $\mathrm{C}$ program is learning that is prepared for learning citizens who need education to a higher level. “...educational programs for citizens to acquire knowledge and skills, acquire life skills, develop professional attitudes and personalities, prepare themselves to strive independently; or continuing education to a higher level" [12].

Learning citizens of paket $\mathrm{C}$ who continue their education at the tertiary level must be equipped with skills that are appropriate to the citizens' learning needs and the development of the technological era in accordance with the curriculum in formal education. The information age reinforced the continuing education, and universities began to serve in the meaning of lifelong learning with their continuing education courses as well as their formal curriculum [13].

Tutor recruitment as a companion in the learning process must have qualifications that are in line with the learning objectives. The recruitment tutor's equivalency tutoring paket $\mathrm{C}$ has an undergraduate qualification, which is in line with the needs of the subjects being taught, aged between 25-45 years and has motivation and enthusiasm for teaching.

The second stage is organizing; at this stage, the tutors as the organizer of the paket $\mathrm{C}$ program have a vital role. Among the role of the tutor is to determine the objectives of learning, learning schedules, places of learning, and skills that will be taught to the learning 
citizens. Therefore, "the design of learning programs is assessed from: (1) aspects of the objectives to be achieved or the competencies to be developed; (2) learning strategies to be applied, and (3) contents of the learning program" [14].

The learning objectives in the paket $\mathrm{C}$ program are to increase the knowledge, skills, and attitudes of the learning citizens. In the paket $\mathrm{C}$ program implemented by the Cerme SKB, there were 20 learning citizens. Learning starts from Monday to Friday at 07.00-14.00 WIB. Whereas the non-regular is held on Saturdays and Sundays. Because the average learning citizens from the non-regular is workers. Time allocation is the result of a learning contract [15].

At the organizing stage, the implementation of learning conducted by tutors uses the K13 curriculum, which is adapted to the Indonesian National Qualification Framework. Learning materials are arranged in writing based on the material needed by learning citizens [16]. Tutors in teaching use the lecture method, brainstorm, and discussion. As for learning techniques during learning activities using demonstration techniques. So that learning citizens have skills and skills at work. Competency refers to the skill, knowledge, and ability required by an individual to perform well in a given profession [17].

To support the learning process, the facilities and infrastructure of the paket $\mathrm{C}$ program are entirely owned by the SKB Cerme Gresik Regency. Infrastructure facilities that are used to support the learning process are six classrooms, which are equipped with tables, chairs, and whiteboard facilities. To support learning, the SKB Cerme library has subject books that fit the needs of the learning population. The cost of education for regular learning citizens is completely free because they get help with the education costs from the government.

The third stage is the mobilization stage; at this stage, it is very related to the learning motivation of the learning citizens. During preliminary observations, learning citizens who attend learning on average have intrinsic motivation. Intrinsic motivation is a motivation that arises from within the learning citizens to learn and obtain education. While the exterinsic motivation that arises in learning citizens is encouragement because it requires a diploma to apply for a job, the prerequisites occupying a job position that requires a minimum qualification to pursue a paket $\mathrm{C}$ equivalent to high school, and for further education requirements.

In the fourth stage, the guidance stage, this stage is the stage used as a benchmark for program evaluation. Because the results of this evaluation become a recommendation whether the $\mathrm{C}$ package program equivalent to high school is in accordance with the implementation in the field, needs to be developed, or needs to be stopped so that the coaching stage includes three aspects, including supervision, investigation, and monitoring.

The supervision aspect is the responsibility of the learning agent as the manager of the paket $C$ program. The tutor supervises when planning, implementing, and learning outcomes of the paket C. So that supervision from the beginning to the end of learning becomes the responsibility of the tutor to learn.

The investigation aspect is the responsibility of each subject's tutor. Therefore, in the learning process, the tutor plays an important role during the learning process. Starting from the learning objectives, learning models, to the techniques used. So that citizens can learn comfortably while participating in learning.

The monitoring aspect is the responsibility of the tutor. So that all have responsibilities in monitoring both the process until the end of learning while at SKB Cerme. Continuous monitoring will facilitate evaluation of learning.

In the fifth stage namely the assessment stage or the final stage in the learning process. This stage becomes a crucial stage as an evaluation material for the institution. The assessment stage is carried out through three stages including: initial assessment, assessment of the learning process, and final assessment of learning. With this assessment stage it becomes a recommendation that the Paket C program is feasible to be continued, developed, or terminated.

Program evaluation can be concluded as a process of finding information, finding information and establishing information that is explained systematically about planning, values, goals, benefits, effectiveness and suitability of something with established criteria and objectives [18].

In the results of the evaluation program research that learning of paket $\mathrm{C}$ in the SKB Cerme Gresik is worthy to be continued. Because learning citizens who take the paket $\mathrm{C}$ education have a lot of interest and are not accommodated in formal education. That way the community believes in the objectives of the Activity Management Team and with that trust motivates the Activity Management Team to work better [19].

Improving the Quality of Learning for Learning Citizens Of Paket C At Sanggar Kegiatan Belajar Cerme Gresik

The learning quality of learning citizens' paket $\mathrm{C}$ in the SKB Cerme Gresik can be assessed from the pretest and post-test scores. Descriptive results indicate that the variables tested previously as a whole have increased. Pre-test and post-test results are shown in Tables 3.1 and 3.2. in table 3.2 illustrates that the negative value between the quality of learning in learning citizens, the mean rank and sum of ranks all have a value of 0 . There is no decrease from the pre-test value to the post-test value.

On the results of the quality of learning all learning citizens, which amounting to 20 learning residents experienced a significant increase. The improvement in the quality of learning the paket $\mathrm{C}$ can be seen from the average value increasing to 10.50 , and the number of positive rankings of 210.00 .

While the value of test statistics in table 3.3 illustrates that the value of Asymp. Sig (2-tailed) of 0, 000 $<0.05$ then the alternative hypothesis is accepted. So the results of the pre-test and post-test illustrate that there are differences in learning outcomes before and after improving the quality of learning the paket $\mathrm{C}$ at SKB Cerme Gresik.

\section{CONCLUSIONS}

The description of the paket $\mathrm{C}$ program at the Sanggar Kegiatan Belajar Cerme in Gresik Regency in its implementation after being evaluated continuously has five stages. The five stages of evaluating the paket $\mathrm{C}$ program in the SKB consist of the first stage of planning such as identifying the needs of the learning citizens, identifying skills, and recruiting tutors of the paket $\mathrm{C}$. The second stage is organizing, starting from the learning objectives, the learning schedule, the place of learning, 
and the skills that will be taught to the learning citizens. The third stage is mobilization, at this stage to bring up the motivation of learning citizens to take part in learning both intrinsic motivation and extrinsic motivation. In the fourth stage is coaching. At this stage, the learning community is assessed for learning outcomes by the tutor and subject tutor. The fifth stage is assessment, at this stage learning citizens are assessed as a whole. Starting from the beginning of learning, the learning process, until the end of learning. On the results of the pre-test and posttest evaluation of learning that there is an increase in the quality of learning on learning citizens of paket $\mathrm{C}$ at SKB Cerme Gresik.

\section{REFERENCES}

[1] Sisdiknas, Sistem Pendidikan Nasional Nomor 20 Tahun 2003. Jakarta, 2003, p. 14.

[2] A. P. A. Dwinata, "Korelasi Antara Kinerja Tutor Dengan Prestasi Belajar Warga Belajar Paket C di Sanggar Kegiatan Belajar Cerme Kabupaten Gresik,” vol. 6, pp. 19, 2017.

[3] S. Arikunto, Evaluasi Program Pendidikan. Jakarta: PT Bumi Aksara, 2014.

[4] Sukardi, Evalusi Pendidikan Prinsip \& Operasionalnya. Jakarta: PT Bumi Aksara, 2015.

[5] K. P. dan Kebudayaan, "Laporan Akuntabilitas Kinerja," Jakarta, 2011.

[6] Roni Anjar Pamungkas, "Evaluasi Program Paket B Setara Smp Pada Sanggar Kegiatan Kegiatan Belajar (Skb) Kulonprogo," Universitas Negeri Yogyakarta, 2014.

[7] "Angka Harapan Sekolah (AHS) Penduduk Jawa Timur Menurut Kabupaten/Kota (IPM Metode Baru), 20102017.'[Online].Available:https://jombangkab.bps.go.id/st atictable/2019/08/07/1252/angka-harapan-sekolah-ahspenduduk-jawa-timur-menurut-kabupaten-kota-ipmmetode-baru-2010-2017.

[8] "Angka Partisipasi Kasar (APK) Jawa Timur Menurut Jenis Kelamin dan Kabupaten/Kota." [Online]. Available: https://jatim.bps.go.id/dynamictable/2019/07/08/82/angka -partisipasi-kasar-apk-jawa-timur-menurut-jenis-kelamindan-kabupaten-kota-2016-.

[9] J. Creswell, Riset Pendidikan, Kelima. Yogyakarta: Pustaka Pelajar, 2015.

[10] Sugiyono, Metode Penelitian Kuantitatif Kualitatif dan $R \& D$. Bandung: Alfabeta, 2012.

[11] D. Rettha, "Evaluasi Program Kesetaraan Paket C Pada Pusat Kegiatan Belajar Masyarakat ( Pkbm ) Negeri 17 Penjaringan, Jakarta Utara, " 2011.

[12] L. Lokollo and J. L. Siang, "Program Evaluation of Community Learning Center (PKBM) Program as Community Learning Resources in Ambon City based on evaluation of the Context," Proceeding Int. Semin. Educ., vol. 2, no. 20, pp. 20-34, 2019.

[13] Mustakim, "Training Management Model For Human Resource Capacity Building (Analysis Of Education And Training Agency, West Java Province , Indonesia)," no. February, pp. 146-155, 2017.

[14] I. Gunawan, "Evaluasi Program Pembelajaran," $J$. Pendidik., no. 1, pp. 1-13, 2011.

[15] Mustakim, "Traditional Internship Pattern in Developing Community Enterpreneurship," Proc. Adv. Soc. Sci. Educ. Humanit. Res., vol. 88, no. Nfe 2016, pp. 214-217, 2017.

[16] Nurheni, "Evaluasi Pelaksanaan Program Kursus Bahasa Inggris Sanggar Kegiatan Belajar (SKB) Propinsi Daerah Istimewa Yogyakarta.” Kalimantan Tengah, pp. 91-102, 2003.

[17] H. Hung, J. W. Altschuld, and Y. Lee, "Exploring training needs of educational program evaluators in the AsiaPacific region," Eval. Program Plann., vol. 35, no. 4, pp. 501-507, 2012

[18] A. P. Munthe, "Pentingya Evaluasi Program Di Institusi Pendidikan: Sebuah Pengantar, Pengertian, Tujuan dan Manfaat," Sch. J. Pendidik. dan Kebud., vol. 5, no. 2, p. $1,2017$.

[19] E. H. Setiawan, "Evaluasi Program Nasional Pemberdayaan,” vol. 1, no. 2, pp. 784-796, 2013. 